\title{
THE IMPACT OF THE VALUE ENGINEERING ON THE DECISION MAKING AND THE DEVELOPMENT OF THE CONSTRUCTION INDUSTRY IN EGYPT
}

\author{
Muhammad, Kh. M. A. \\ Al- Sharabyia Quarter, Cairo Governorate
}

\begin{abstract}
The construction industry is concerned with satisfying its customers' needs through delivering projects that achieve their objectives and meet their expectations on time, within budget and as specified. Despite the several housing programmes constructed by government authorities, there is a real housing problem for the poor. This problem is attributed to a number of reasons. Amongst them, the $\mathrm{T}$ inability of the low-incomers to cover the cost of supplied houses and the lack of the constructed projects to achieve users' satisfaction. This highlighted the need to develop innovative and creative solutions that can deliver housing projects that achieve the satisfaction of their users and at the most-cost effective manner simultaneously. This aim will be achieved through incorporating the concepts of Value Management $(\mathrm{VM})$ and Risk Management (RM) in developing housing projects for the poor. Towards studies of low-income housing projects constructed by the government of the United Arab Emirates (UAE) in Musaffah commercial city. Finally, outlining the research recommendations for government authorities, design firms and construction professionals concerned with housing projects for the poor.
\end{abstract}

Keywords: Customer satisfaction, Value management, Risk management, Low cost housing.

\section{INTRODUCTION}

The Value Engineering is an intensive, interdisciplinary problem solving activity that focuses on improving the value of the functions that are required 
to accomplish the goal, or objective of any product, process, service, or organization. Value Engineering stands to a reason that any technique so useful should be applied to every product, and at each stage of the normal day-to-day development of a building construction product. The practice of this technique requires a certain amount of expense, which may get justified by potential cost savings. Accordingly there must be a recognized need for change and a distinct opportunity for financial benefit to deserve the added cost of a value engineering effort. Value Engineering is an creative and disciplined process which seeks to offer the client a reliable opportunity for cost savings without detriment to quality or performance.

\section{Historical Background:}

During the World War II, General Electric Company (GE) faced the problem of scarcity of critical materials to fulfil the demand of the war equipment. To overcome that problem, GE had to use substitute materials for those in shortage. Many of the substitutes were less expensive and better in performance. In 1947, a staff engineer for GE developed a number of ideas and techniques to select alternative materials that could be used internationally. His main attitude was to search for value in a product and he developed a function-based methodology that was successfully proven. The new methodology was so successful that it was possible to produce goods at greater production and operational efficiency and at lower costs. As a result of its success, GE formed a special group leaded by Larry Miles to refine the methodology. In 1954, the U.S Navy Bureau of Ships used the Value Analysis process to cost improvement during design. They called it "Value 
Engineering". The Value Engineering was used formally in the U.S Department of Defense in 1961.

\section{Value Engineering Benefits:}

According to research carried out by SAVE, VM methodology can increase customer satisfaction and add value to an organization's investment in any business or economic setting. Practitioners apply VM methodology to products and in industries such as the following: corporations and manufacturing, construction, transportation, government, health care and environmental engineering. Further from the research they found out that VM methodology easily produces savings of $30 \%$ of the estimated cost for manufacturing a product, constructing a project or providing a service. The return on investment that public and private organizations derive from implementing VM programs averages from 10 to 1 . That is, for every dollar invested in a VM study, including participants' time and implementation costs, 10 dollars in net saving results.

\section{Value Engineering Methodology:}

The value methodology is a systematic process that follows the Job Plan. The Job Plan consists of some phases. The recommended VE methodology (Job Plan) used by the VE team during the Workshop has five distinct phases. Briefly, these phases are:

\section{A. Information Phase:}

The VE team gains as much information as possible about the project design, background, constraints, and projecte costs. The team performs a function analysis and relative cost ranking of systems and sub-systems to identify potential high cost areas. The information phase also includes 
preparation of the cost and energy models from cost data assembled before the workshop began. These models are updated based on information received during the Designer"s presentation.

\section{B. Function and Creative Phase:}

The VE team uses a creative group interaction process to identify alternative ideas for accomplishing the function of a system or sub-system. Functional analysis forces a broader and more comprehensive understanding of the project by Stimulating intense discussion and by compelling the team to view aspects they might not normally have considered VE team evaluates the ideas developed during the creative phase.

\section{Evaluation/Analytical Phase:}

The ideas generated during the Speculative/Creative Phase are screened and evaluated by the team. The ideas showing the greatest potential for cost savings and project improvement are selected for further study. VE team evaluates the ideas developed during the creative phase. The VE team ranks the ideas. Ideas found to be irrelevant or not worthy of additional study are disregarded; those ideas that represent the greatest potential for cost savings and improvements are selected for development.

\section{Development/Recommendation Phase:}

The VE team researches the selected ideas and prepares descriptions, sketches and life cycle cost estimates to support the recommendations as formal VE proposals. During the development phase of the VE study each designated idea is expanded into a workable solution. The development consists of the recommended design, capital and life cycle cost comparisons 
and a descriptive evaluation of the advantages and disadvantages of the proposed recommendations.

\section{E. Report Phase}

The VE consultant will work in concert with the A-E and the PBS representative to produce a preliminary written VE Report which is intended to represent the results of the VE workshop activities, and meet the VE Program objectives.

The post-study portion of a VE study includes the finalization of the VE Report in order to incorporate the VE proposals developed during the workshop. The Designer then responds by accepting and incorporating the proposals into the project design, rejecting the proposals, or recommending further study.

\section{DATA ANALYSIS:}

Masterformat is a standard for organizing specifications and other written information for commercial and institutional building projects and Uniformat is a standard for classifying building specifications, cost estimating, and cost analysis in the U.S. and Canada. The elements are major components common to most buildings.

Case study of residential building has taken to study value engineering application. In this Master format and uniformat was prepared. After preparation of master format and uniformat next step is to apply Pareto Law 20/80. which comes through ranking of the function according to their costs in descending order. Normally, around $20 \%$ of the functions constitute around $80 \%$ of the cost. These functions $(20 \%)$ are the subject of value engineering. 
J. Environ. Sci.

Institute of Environmental Studies and Research - Ain Shams University

Weight for each criterion is assigned to reflect relative importance based on the project attributes that has been clearly verified and defined.

Table I: Functions of Uniformaranked In Descending Order

\begin{tabular}{|l|l|c|c|c|c|}
\hline Code & Uniformat & Cost (Rs.) & $\begin{array}{l}\% \text { of } \\
\text { the } \\
\text { Total } \\
\text { Cost }\end{array}$ & $\begin{array}{c}\text { Accumulative } \\
\text { Cost }\end{array}$ & $\begin{array}{c}\text { \% } \\
\text { Accumulative }\end{array}$ \\
\hline \hline 031 & Flooring & $2,90,520$ & $15.00 \%$ & $2,90,520$ & $15.00 \%$ \\
\hline 043 & Door \& Window & $2,52,520$ & $13.04 \%$ & $5,43,040$ & $28.04 \%$ \\
\hline 022 & Centering Work & $2,23,476$ & $11.54 \%$ & $7,66,516$ & $39.58 \%$ \\
\hline 051 & Plastering & $1,56,880$ & $8.10 \%$ & $9,23,396$ & $47.68 \%$ \\
\hline 021 & Slab & $1,43,710$ & $7.42 \%$ & $10,67,106$ & $55.1 \%$ \\
\hline 024 & Beams & $1,24,361$ & $6.42 \%$ & $11,91,467$ & $61.52 \%$ \\
\hline 041 & Painting & 10,4000 & $5.37 \%$ & $12,95,467$ & $66.89 \%$ \\
\hline 061 & Plumbing & $1,00,000$ & $5.16 \%$ & $13,95,467$ & $72.05 \%$ \\
\hline 011 & Stepped Foundation & 92,958 & $4.80 \%$ & $14,88,425$ & $76.85 \%$ \\
\hline 025 & Brickwork & 83,916 & $4.33 \%$ & $15,72,341$ & $81.18 \%$ \\
\hline 023 & Column & 81,386 & $4.20 \%$ & $16,53,727$ & $85.38 \%$ \\
\hline 092 & Profit and Power & 76,000 & $4.00 \%$ & $17,29,727$ & $89.38 \%$ \\
\hline 081 & $\begin{array}{l}\text { Light } \\
\text { Distribution }\end{array}$ & $3.87 \%$ & $18,04,727$ & $93.25 \%$ \\
\hline 042 & Carpentry Work & 62,600 & $3.23 \%$ & $18,67,327$ & $96.48 \%$ \\
\hline 091 & $\begin{array}{l}\text { General Condition } \\
\text { Overhead }\end{array}$ & 36,906 & $1.90 \%$ & $19,04,233$ & $98.38 \%$ \\
\hline 101 & Equipment & 32,097 & 1.62 & $19,36,330$ & $100 \%$ \\
\hline 012 & Spec. foundations & 0 & $0 \%$ & $19,36,330$ & $100 \%$ \\
\hline 082 & Special electrical system & 0 & $0 \%$ & $19,36,330$ & $100 \%$ \\
\hline & Total & $19,36,330$ & & & \\
\hline
\end{tabular}

It was noticed that the first 6 items (out of 16) forms $61.53 \%$ of the total cost. This means $37.5 \%$ of the functions form $61.53 \%$ of the cost which is very closed to Pareto Law. As a conclusion, the area of value engineering analysis and study will be controlled by the first six functions that are listed in following table. 


\begin{tabular}{|l|l|l|}
\hline Code & Uniformat & Cost $($ Rs. $)$ \\
\hline \hline 031 & Flooring & $2,90,520$ \\
\hline 043 & Door and Window & $2,52,520$ \\
\hline 022 & Cantering Work & $2,23,476$ \\
\hline 051 & Plastering & $1,56,880$ \\
\hline 021 & Slab & $1,43,710$ \\
\hline 0214 & Beams & $1,24,361$ \\
\hline \multicolumn{2}{|l}{ Total } & $11,91,467$ \\
\hline
\end{tabular}

\section{CONCLUSIONS}

Value Engineering can be applied during any stage of a project's design development cycle. However, the greatest benefit and resource saving are typically achieved early in the development and conceptual design stages. VE may be applied more than once during the life of the project. Early application of VE helps to get the project started in the direction, and repeated application helps to filter the project's direction based on new or changing information. It is important available and compare quality elements of the design with the owner's requirements. The application of Pareto Law 20/80 states that around $20 \%$ of the functions constitute around $80 \%$ of the cost. These functions (20\%) are the subject of value engineering. Likewise It was noticed that the first 6 items (out of 16) forms $61.53 \%$ of the total cost. This means $37.5 \%$ of the functions form $61.53 \%$ of the cost which is very closed to Pareto Law. As a conclusion, the area of value engineering analysis and study will be controlled by the first six functions. Further, we can do analysis of these functions and suggest alternatives and calculate cost model after application of value engineering technique. 
J. Environ. Sci.

Institute of Environmental Studies and Research - Ain Shams University

\section{REFERENCES}

A. J. Dell'Isola. February 1969 "Value Engineering Cost Effectiveness... A Tool for the Designer too" "A Value Engineering Methodology for low income Housing Projects in Gaza Strip"

Srinath Perera, Gayani Karunasena, Kaushalya Selvadurai. February 1996 "Application of value management in construction

Nick Rich. January 2000 "Value analysis Value Engineering" Lean Enterprize Research Centre,United kingdom, Abdulaziz S. Al-Yousefi, "value Engineering application benefits in sustainable construction." Saudi Arabia

NIU Ting, LUO Fuzhou. January 2007“Application of value management when allocating Construction site", Management School, Xi'an University of Architecture and Technology, P.R.China, 710055

Muthiah Kasi. C.V.S. January 2004"An Introduction to Value Analysis and Value Engineering for architects, engineers and Builders" University of Wisconsin-Extension Independent study

George H. Fridholm. December 1997“Value Engineering-Dynamic Tool for Profit Planning" Chairman of George Fridholm Associates

U.S. General Services Administration Public Buildings Service.December 1992 "Value EngineeringProgram Guide for Design and Construction", Volume 1 Internal Operations and Management, PBS-PQ250

The federal facilities council ad hoc task group on integrating Sustainable design, life-cycle costing, and value engineering Into facilities acquisition. Washington, D.C. 2001 "Sustainable Federal Facilities A guide to integrating Value engineering,life cycle costin, and Sustainable Development", Report No.142

Pergamon Press Ltd. February 1969 "Value engineering”, Vol.1 No. 5

Office of Quality Assurance. November 2009 "Value engineering Program", Connecticut department of transportation Bureau of engineering and construction, 
Office of Quality Assurance. November 2016 "Value engineering Program", Connecticut department of transportation Bureau of engineering and construction,

N.C.Narayanan. November 2017"Value Engineering the DMAIC way", Indian Value Engineering Society (INVEST), 2nd Asian Value Engineering

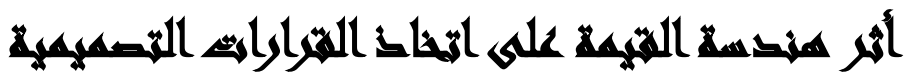

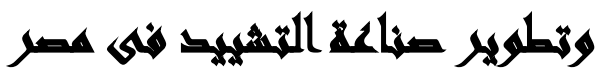

[

\author{
خالد محمد علي محمد \\ حي الثرابية، محافظة القاهرة محثل
}

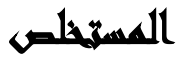

تهنم صناعة التشييد والبناء بتلبية حاجات عملائها من خلال تتفيذ مشروعات تحقق اهدافهر

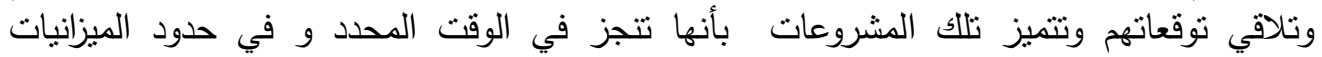

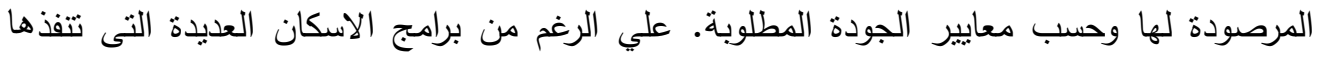

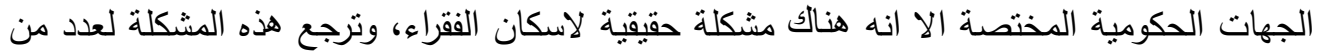

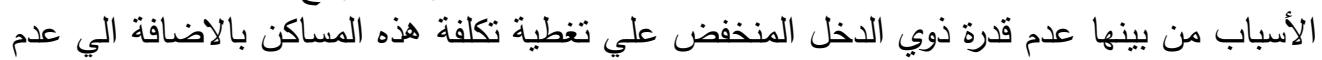

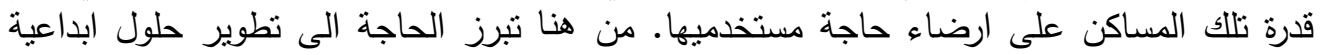

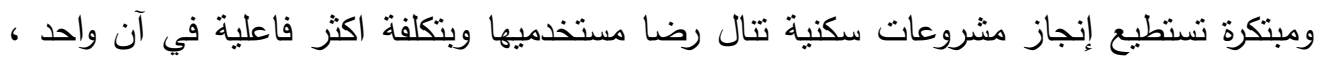

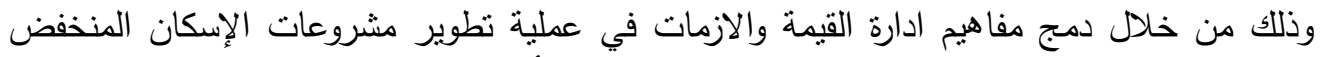

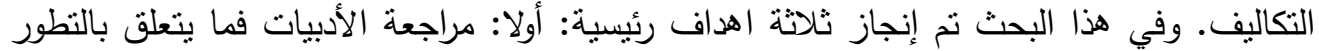

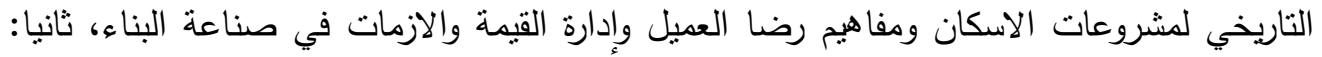

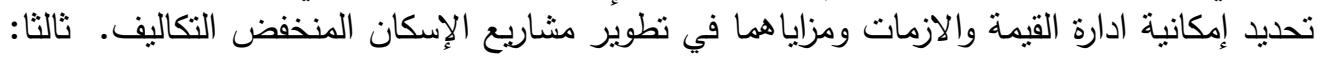

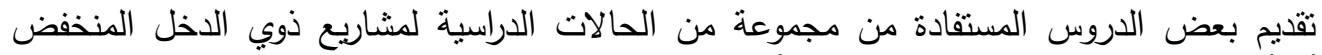

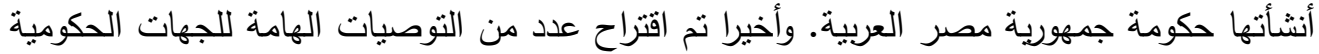

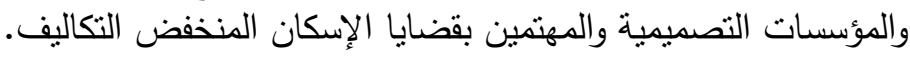

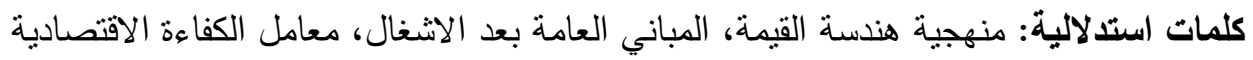

